\title{
Commentaries
}

\section{Who Coined the Concept of Ethnocentrism? A Brief Report}

\author{
Boris Bizumic ${ }^{\text {a }}$
}

[a] Research School of Psychology, the Australian National University, Canberra, ACT, Australia.

\begin{abstract}
It is widely assumed that Sumner coined the concept of ethnocentrism in 1906. This attribution is prominent in psychology and the social sciences and is found in major works on ethnocentrism, intergroup relations, and prejudice. A review of classic sources written in German, Polish, and English shows that the concept had existed in numerous publications for at least several decades before Sumner's writings on ethnocentrism (e.g., Gumplowicz, 1879, 1881). This article presents early conceptualizations of ethnocentrism and potential influences on Sumner. It also discusses implications of this conceptual history, such as biases that may have contributed to the widespread belief that Sumner coined the concept. It is argued that psychologists and other social scientists should stop attributing the origin of the concept to Sumner, despite his important role in popularizing it, and, in general, should engage more with their intellectual history in different languages.
\end{abstract}

Keywords: ethnocentrism, prejudice, intergroup relations, ethnicity, conceptual history

Journal of Social and Political Psychology, 2014, Vol. 2(1), 3-10, doi:10.5964/jspp.v2i1.264

Received: 2013-09-16. Accepted: 2014-01-20. Published (VoR): 2014-01-31.

Handling Editor: Johanna Ray Vollhardt, Department of Psychology, Clark University, Worcester, MA, USA

${ }^{*}$ Corresponding author at: Research School of Psychology, the Australian National University, Building 39 Science Road, Canberra, ACT 0200, Australia. E-mail: Boris.Bizumic@anu.edu.au This is an open access article distributed under the terms of the Creative Commons Attribution License
(http://creativecommons.org/licenses/by/3.0), which permits unrestricted use, distribution, and reproduction in any medium, provided the
original work is properly cited.

Ethnocentrism is one of the fundamental concepts in psychology and the social sciences. The phenomenon of ethnocentrism is widely studied in psychology, often referring to the concept of ethnocentrism itself, and more recently using the concept of ingroup bias, which is "the laboratory analogue of real-world ethnocentrism" (Tajfel \& Turner, 1986, p. 13). It has now become a (very widely cited) truism in psychology and the social sciences that William Graham Sumner, in his highly important book, Folkways (Sumner, 1906), introduced three fundamental concepts: ethnocentrism, ingroup, and outgroup. Indeed, the two most widely cited books on ethnocentrism state: "First introduced and used descriptively by Sumner in 1906, the term had the general meaning of provincialism or cultural narrowness; it meant a tendency in the individual to be 'ethnically centered,' to be rigid in his acceptance of the culturally 'alike' and in his rejection of the 'unlike"' (Adorno, Frenkel-Brunswik, Levinson, \& Sanford, 1950, p. 102), and "In his Folkways of 1906, William Graham Sumner contributed to modern social science the widely used concepts of ingroup, outgroup, and ethnocentrism" (LeVine \& Campbell, 1972, p. 7). Similarly, Tajfel (1982), in his influential review of social psychology of intergroup relations in the Annual Review of Psychology, writes: "Sumner (1906) was the first to use the term [ethnocentrism] together with those of 'ingroup' and 'outgroup"' (p. 
7). Similar pronouncements about Sumner as the originator of the concept are too many to cite and continue to this date. For example, Kinder and Kam (2009) begin their recent book on ethnocentrism with: "Ethnocentrism is an ancient phenomenon but it is a modern word, invented at the opening of the twentieth century by William Graham Sumner, an eminent professor of political and social science at Yale" (p. 1). These authors later add: "We are indebted to Sumner for noticing ethnocentrism in the first place, for naming it felicitously, for defining it sensibly" (Kinder \& Kam, 2009, p. 29).

Certain sources tend to disagree and credit other publications with using the concept of ethnocentrism before Sumner's 1906 book. For example, the Oxford English Dictionary (Simpson \& Weiner, 1989) points out that a paper by McGee (1900) used the concept (more precisely, the term "ethnocentric") probably for the first time in the English language (see also Bizumic \& Duckitt, 2012'; van der Geest, 2005). On the other hand, Bracq (1902) and Banton (1998) argue that the real originator of the concept was Ludwig Gumplowicz, with Banton pointing out one book, written in German, by Gumplowicz (1881). LeVine (2001), although acknowledging that Gumplowicz's ideas had influenced Sumner, still argued that Sumner may have invented the concept.

\section{The Concept of Ethnocentrism in Gumplowicz's Writings}

A review of classic sources reveals that it was probably Gumplowicz who used the concept of ethnocentrism (more specifically, "Ethnocentrismus") for the first time in print. In fact, there are at least eight of his publications (five books and a paper written in German, and one book and a paper written in Polish) that had used the concept before Sumner's 1906 book (Gumplowicz, 1879, 1881, 1883, 1884, 1887, 1892, 1895, 1905). Gumplowicz saw ethnocentrism as a similar phenomenon, or more correctly a "delusion", to geocentrism (the belief that the Earth has the central position in the universe) and anthropocentrism (the belief that humans have the central position on the Earth), but focusing on one's own ethnic group (nation, people). This belief in centrality is reflected in the view that the group is extraordinary, superior, and better in relation to any other group - and not only any other existing group, but any group that has ever existed. For example, in 1883 Gumplowicz wrote: "So far most writing of history is dominated by limited ethnocentric viewpoints. . . One can comfortably say that the largest part of historical writing so far actually has only sprung from this subjective need of human beings to glorify their own

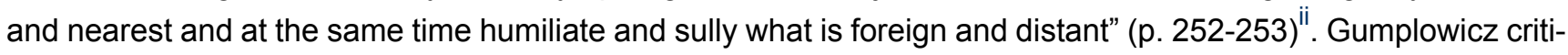
cized his contemporaries for ethnocentric biases and argued that social scientists need to transcend these in order to develop better and more objective social science.

In his writings, Gumplowicz also noted many examples of ethnocentrism. He pointed out ethnocentrism among the ancient Greeks, who believed that all other groups are barbarian (Gumplowicz, 1887). Similarly, Gumplowicz (1892) saw ethnocentrism in Aristotle's claim that positive qualities are perfectly balanced only in Greeks, whereas other groups are somewhat deficient in positive qualities. He also saw ethnocentrism in Hegel's statement that Germans represent the objective spirit and therefore may be seen as godlike (Gumplowicz, 1895). Furthermore, Gumplowicz pointed out ethnocentrism among the French, who believed themselves to be more civilized than other groups (Gumplowicz, 1887), among the Chinese, who saw their country to be in the middle of the world (Gumplowicz, 1895), and among the Jews, who believed themselves to be God's chosen people (Gumplowicz, 1895). He also wrote about many ethnic groups having ethnocentric religious myths that assume that the first human couple originated in their own ethnic group, which suggests that all humans descended from that group (Gumplowicz, 1881). 


\section{Influence of Gumplowicz's Conceptualizations on Sumner and Other Early Social Scientists}

Although not widely known today among psychologists, Gumplowicz was one of the founders of sociology and influential during its early stages. He believed that groups should be the main unit of analysis in sociology and argued for a sociology of intergroup relations, which he saw to primarily involve a study of intergroup conflict. Some of his central ideas have had a direct and indirect influence on several important sociologists, including Ward, Sumner, Mosca, and possibly Durkheim (Adamek \& Radwan-Praglowski, 2006; see also Horowitz's introduction to Gumplowicz, 1905/1963). Sumner himself was particularly influenced by Gumplowicz's realpolitik approach to intergroup conflict and war (Bannister, 1991). Moreover, Gumplowicz belonged to the group of four thinkers (the others were Comte, Spencer, and Marx) who had exerted the most influence on early American sociology (Martindale, 1976).

It should be pointed out that one century ago German publications were widely read in the United States, and Sumner, like other U.S. social scientists, was strongly influenced by social scientists who wrote in German. For example, the reference list in Folkways (Sumner, 1906) included many publications in German - as well as publications in other foreign languages. Sumner (1906, 1911, 1913; Sumner, Keller, \& Davie, 1927) also cited Gumplowicz's books, including those that explicitly discussed ethnocentrism (i.e., Gumplowicz, 1883, 1892), but without linking Gumplowicz with the concept of ethnocentrism. In light of this, it is possible that Sumner had taken the concept of ethnocentrism from Gumplowicz, but failed to acknowledge it (see Banton, 1998). Sumner, however, may have also taken the concept from others who had in turn taken it from Gumplowicz. This seems unlikely because Sumner was familiar with Gumplowicz's books that discussed ethnocentrism and because, furthermore, there are a number of parallels between Sumner's and Gumplowicz's ideas about ethnocentrism and intergroup relations.

Gumplowicz and Sumner defined ethnocentrism similarly as a belief that one's own group is of central importance and better than any other. Sumner (1911), however, included additional intragroup (e.g., devotion, group cohesion) and intergroup characteristics (e.g., defense of ingroup interests against outgroups) in his conceptualization of ethnocentrism. Certain examples of ethnocentrism that Sumner (1906) described could be found in earlier Gumplowicz's writings. For example, these include several examples mentioned above, such as the widespread myth that the human origin is in one's own ethnic group, the Greeks perceiving other groups as barbarians, the Chinese calling their country the "Middle Kingdom", or the Jews' belief that they are the "chosen people".

Moreover, Gumplowicz's early version of realistic group conflict theory assumed that ethnic groups are often in conflict because of conflicting realistic (economic, material) interests. He theorized that group cohesion and syngenism (which correspond to ingroup positivity) bring about exploitation and subordination of other groups as well as hostility towards them (which correspond to group self-centeredness and outgroup negativity). This is very similar to Sumner's well-known theoretical postulate of the association between pro-ingroup and anti-outgroup attitudes (Sumner, 1906), and the idea that group cohesion and devotion lead to ethnocentric superiority and exploitativeness (Sumner, 1911). Additionally, like Gumplowicz before him, Sumner saw very close links between religion and ethnocentrism. 
Although one should not ignore that both Gumplowicz and Sumner were influenced by other social scientists of the time, it is clear that when it comes to ethnocentrism, Gumplowicz had used the concept in a similar way to Sumner, but before him. In addition, it is also clear that Gumplowicz had influenced Sumner's theorizing about ethnocentrism and intergroup relations. It is, however, peculiar that Sumner's (1906) widely-cited section on ethnocentrism did not cite Gumplowicz.

There are other authors, writing in English, who had also used the concept of ethnocentrism before Sumner, and who were probably also influenced by Gumplowicz. For example, in addition to the paper published in 1900, another paper by McGee (1898) had used the concept. Discussing his anthropological work with Seri Indians, McGee claimed that their way of thinking was "tribe-centered (or ethnocentric)" because "they view extraneous things, especially those of animate nature, with reference to the tribe" (McGee, 1898, p. 154). Sumner cited this description of Seri Indians as an example of strong ethnocentrism, but did not acknowledge that McGee had also used the concept. Other social scientists, such as Evans (1891, 1894), Keller (1900), and Bracq (1902), had used the concept before Sumner, with Bracq attributing it to Gumplowicz.

\section{Implications of the Conceptual History of Ethnocentrism}

Although the early conceptual history of ethnocentrism is blurred, it appears that, contrary to popular opinion and major writers on ethnocentrism, Sumner did not coin the concept in 1906. To make it clear, Sumner did not claim that he had invented the concept. He merely omitted to acknowledge that anyone else before him had used it. This is not unusual, as most early authors who wrote on ethnocentrism failed to credit anyone with the concept. In fact, looking back almost one and a half centuries, it is not implausible that Gumplowicz might have borrowed the concept from another, perhaps unpublished, source. It is, nevertheless, Sumner who promoted and popularized the concept. Sumner also presented a concise and forceful treatment of ethnocentrism, and he defined ethnocentrism clearly and elaborately. Without his influence, ethnocentrism might have never become a fundamental social scientific concept.

This might also explain why so many researchers and theorists credited Sumner with inventing the concept. They relied on Sumner's authority and influence. Accordingly, his omission to say that anybody had used the concept before him was understood as if no one else had used the concept before him. Social scientists, therefore, at one point started giving Sumner an undue credit for inventing the concept, and most authors-including Adorno et al. (1950), LeVine and Campbell (1972), and Tajfel (1982)—seemed to accept this general, though incorrect, knowledge.

This was made easier due to two biases. The first is the tendency of many psychologists and social scientists to be relatively uninterested in the intellectual history of their own and related disciplines, and to focus mainly on hot topics in their areas of specialization (see Andreski, 1972; Nisbett, 1990; Oishi, Kesebir, \& Snyder, 2009). The second bias is possibly more sinister and ironic. Gumplowicz's books and papers were written primarily in German and Polish, and despite his prolific output, only one of his books, The Outlines of Sociology, seems to be translated into English (Gumplowicz, 1885/1899, with the second edition published in 1905/1963). This book, however, did not mention the concept of ethnocentrism. Likewise, several of his papers in English also did not use the concept. Accordingly, there may be a somewhat ethnocentric tendency among English speaking psychologists and social scientists, even those who have extensively studied ethnocentrism, to ignore the work even by a prominent author 
such as Gumplowicz, because almost all of his publications were written in foreign languages and were unavailable in English.

This early conceptual history also shows that there is an unacknowledged debt that contemporary social scientists, and in particular social psychologists, owe to Gumplowicz. Gumplowicz's concept and theory influenced Sumner's theorizing about ethnocentrism, ingroups, and outgroups, and these in turn have influenced generations of social scientists. Although both Gumplowicz and Sumner were sociologists, other disciplines have adopted and accommodated the concept. Nevertheless, different disciplines and individual researchers conceptualized ethnocentrism in very different ways (see Bizumic \& Duckitt, 2012).

The concept of ethnocentrism particularly influenced theories and research in social psychology. ${ }^{\text {iii }}$ This influence has been very prominent in the fields of prejudice and intergroup relations. Indeed, major social psychological theories in these fields, such as authoritarian personality theory (Adorno et al., 1950), realistic group conflict theory (LeVine \& Campbell, 1972), and social identity theory (Tajfel \& Turner, 1986), were developed, at least in part, to explain ethnocentrism. Moreover, Gumplowicz's writings on ethnocentrism prefigure ideas that appear in contemporary social psychology journals. For example, Gumplowicz $(1883,1887)$ linked ethnocentrism with the idea of how one's own present-day ethnic group best represents humankind, whereas all other groups are perceived to be at least somewhat deficient in humanity when compared with one's own group. This is reminiscent of infrahumanization (Vaes, Paladino, Castelli, Leyens, \& Giovanazzi, 2003), a tendency to perceive more humanity in one's own ingroup than in outgroups; and of the ingroup projection model (Wenzel, Mummendey, \& Waldzus, 2007), which posits that ethnocentrism is an outcome of a process in which a superordinate category is better represented by one's own group than by other subgroups.

\section{Conclusions}

A conclusion of this brief conceptual history is that the widely held myth about Sumner coining the concept of ethnocentrism should be dispelled. Future writers on ethnocentrism should, therefore, stop giving Sumner an undue credit for the development of the concept, although Sumner's role in making the concept widely known and offering a strong treatment should not be minimized either. Although Gumplowicz's writings on ethnocentrism, being interspersed with other ideas, could be found in a number of his books and papers, future authors writing on ethnocentrism may want to state that the first printed use of the concept seems to be in Gumplowicz (1879).

This brief conceptual history should also encourage psychologists and other social scientists to focus more on the history of their and related disciplines, including the literature that is published in different languages. This can be achieved by promoting international collaboration, publishing abstracts in several languages, and learning different languages. It is, in conclusion, essential for theorists and researchers to be more open to both historical and contemporary psychology and social scientific literature published in languages other than English.

\section{Notes}

i) This attribution was rectified in a corrective note (Bizumic \& Duckitt, 2013).

ii) I would like to thank Bernd Heubeck for translation. 
iii) Social psychology as a discipline was originally created by integrating sociology and psychology, but their link was severed in the second half of the twentieth century (see Oishi et al., 2009).

\section{Funding}

The author has no funding to report.

\section{Competing Interests}

The author has declared that no competing interests exist.

\section{Acknowledgments}

I would like to thank Bernd Heubeck, Elizabeth Huxley, three anonymous reviewers and the editor for their very useful comments. I am also grateful to Bernd Heubeck for German translation.

\section{References}

Adamek, W., \& Radwan-Praglowski, J. (2006). Ludwik Gumplowicz: A forgotten classic of European sociology. Journal of Classical Sociology, 6, 381-398. doi:10.1177/1468795X06069685

Adorno, T. W., Frenkel-Brunswik, E., Levinson, D. J., \& Sanford, R. N. (1950). The authoritarian personality. New York, NY: Harper.

Andreski, S. (1972). Social sciences as sorcery. London, United Kingdom: Deutsch.

Bannister, R. C. (1991). Sociology and scientism: The American quest for objectivity, 1880-1940. Chapel Hill, NC: UNC Press.

Banton, M. (1998). Racial theories (2nd ed.). Cambridge, United Kingdom: Cambridge University Press.

Bizumic, B., \& Duckitt, J. H. (2012). What is and is not ethnocentrism? A conceptual analysis and political implications. Political Psychology, 33, 887-909. doi:10.1111/j.1467-9221.2012.00907.x

Bizumic, B., \& Duckitt, J. H. (2013). Corrective note for "What is and is not ethnocentrism? A conceptual analysis and political implications." Political Psychology, 34, 693-694. doi:10.1111/pops.12076

Bracq, J. C. (1902). A stronger sense of international justice needed. In W. R. Rose (Ed.), Report of the Eighth Annual Lake Mohonk Conference on International Arbitration (pp. 18-22). Mohonk Lake, NY: The Lake Mohonk Arbitration Conference.

Evans, E. P. (1891). Progress and perfectability in the lower animals. The Popular Science Monthly, 40, 170-179.

Evans, E. P. (1894). The ethics of tribal society. The Popular Science Monthly, 44, 289-307.

Gumplowicz, L. (1879). Das Recht der Nationalität und Sprachen in Oesterreich-Ungarn [The right of nationality and languages in Austria-Hungary]. Innsbruck, Austria: Wagner'sche Universitäts-Buchhandlung.

Gumplowicz, L. (1881). Rechtsstaat und Socialismus [Legal state and socialism]. Innsbruck, Austria: Wagner’sche Universitäts-Buchhandlung.

Gumplowicz, L. (1883). Der Rassenkampf: Sociologische Untersuchungen [The racial struggle: Sociological studies]. Innsbruck, Austria: Wagner'sche Universitäts-Buchhandlung.

Gumplowicz, L. (1884). Macierzyńtwo [Maternity]. Prawda, 14, 159-160. 
Gumplowicz, L. (1887). System socyologii [System of sociology]. Warsaw, Poland: Spolka Nakladowa.

Gumplowicz, L. (1892). Die sociologische Staatsidee [The sociological idea of state]. Graz, Austria: Leuschner \& Lubensky.

Gumplowicz, L. (1895). Sociale Sinnestäuschungen [Social illusions]. Neue Deutsche Rundschau, 6, 1-11.

Gumplowicz, L. (1899). The outlines of sociology (F. W. Moore, Trans.). Philadelphia, PA: American Academy of Political and Social Science. (Original work published 1885)

Gumplowicz, L. (1905). Geschichte der Staatstheorien [History of theories of state]. Innsbruck, Austria: Wagner'sche Universitäts-Buchhandlung.

Gumplowicz, L. (1963). Outlines of sociology (2nd ed., F. W. Moore, Trans., I. L. Horowitz, Ed.). New York, NY: Paine-Whitman Publishers. (Original work published 1905)

Keller, A. G. (1900). Sociology and the epic. American Journal of Sociology, 6, 267-271. doi:10.1086/210967

Kinder, D. R., \& Kam, C. D. (2009). Us against them: Ethnocentric foundations of American opinion. Chicago, IL: The University of Chicago Press.

LeVine, R. A. (2001). Ethnocentrism. In Neil J. Smelser \& Paul B. Baltes (Eds.), International encyclopedia of the social and behavioral sciences (pp. 4852-4854). Oxford, United Kingdom: Pergamon.

LeVine, R. A., \& Campbell, D. T. (1972). Ethnocentrism: Theories of conflict, ethnic attitudes, and group behavior. New York, NY: Wiley.

Martindale, D. (1976). American sociology before World War II. Annual Review of Sociology, 2, 121-143. doi:10.1146/annurev.so.02.080176.001005

McGee, W. J. (1898). The Seri Indians. Annual Report of the Bureau of American Ethnology, 17(1895-1896), Part 1, 1-344.

McGee, W. J. (1900). Primitive numbers. Annual Report of the Bureau of American Ethnology, 19(1897-1898), Part 2, 825-851.

Nisbett, R. E. (1990). The anti-creativity letters: Advice from a senior tempter to a junior tempter. The American Psychologist, 45, 1078-1082. doi:10.1037/0003-066X.45.9.1078

Oishi, S., Kesebir, S., \& Snyder, B. H. (2009). Sociology: A lost connection in social psychology. Personality and Social Psychology Review, 13, 334-353. doi:10.1177/1088868309347835

Simpson, J. A., \& Weiner, E. S. C. (Eds.). (1989). The Oxford English Dictionary (2nd ed., Vol. 5). Oxford, United Kingdom: Clarendon Press.

Sumner, W. G. (1906). Folkways: A study of the sociological importance of usages, manners, customs, mores, and morals. Boston, MA: Ginn and Company.

Sumner, W. G. (1911). War and other essays. New Haven, CT: Yale University Press.

Sumner, W. G. (1913). Earth-hunger and other essays. New Haven, CT: Yale University Press.

Sumner, W. G., Keller, A. G., \& Davie, M. R. (1927). The science of society. New Haven, CT: Yale University Press.

Tajfel, H. (1982). Social psychology of intergroup relations. Annual Review of Psychology, 33, 1-39. doi:10.1146/annurev.ps.33.020182.000245

Tajfel, H., \& Turner, J. C. (1986). The social identity theory of intergroup behavior. In S. Worchel \& W. G. Austin (Eds.), Psychology of intergroup relations (2nd ed., pp. 7-24). Chicago, IL: Nelson Hall. 
Vaes, J., Paladino, M. P., Castelli, L., Leyens, J. P., \& Giovanazzi, A. (2003). On the behavioral consequences of infrahumanization: The implicit role of uniquely human emotions in intergroup relations. Journal of Personality and Social Psychology, 85, 1016-1034. doi:10.1037/0022-3514.85.6.1016

van der Geest, S. (2005). Introduction: Ethnocentrism and medical anthropology. In S. van der Geest \& R. Reis (Eds.), Ethnocentrism: Reflections on medical anthropology (2nd ed., pp. 1-23). Amsterdam, the Netherlands: Het Spinhuis Publishers.

Wenzel, M., Mummendey, A., \& Waldzus, S. (2007). Superordinate identities and intergroup conflict: The ingroup projection model. European Review of Social Psychology, 18, 331-372. doi:10.1080/10463280701728302 